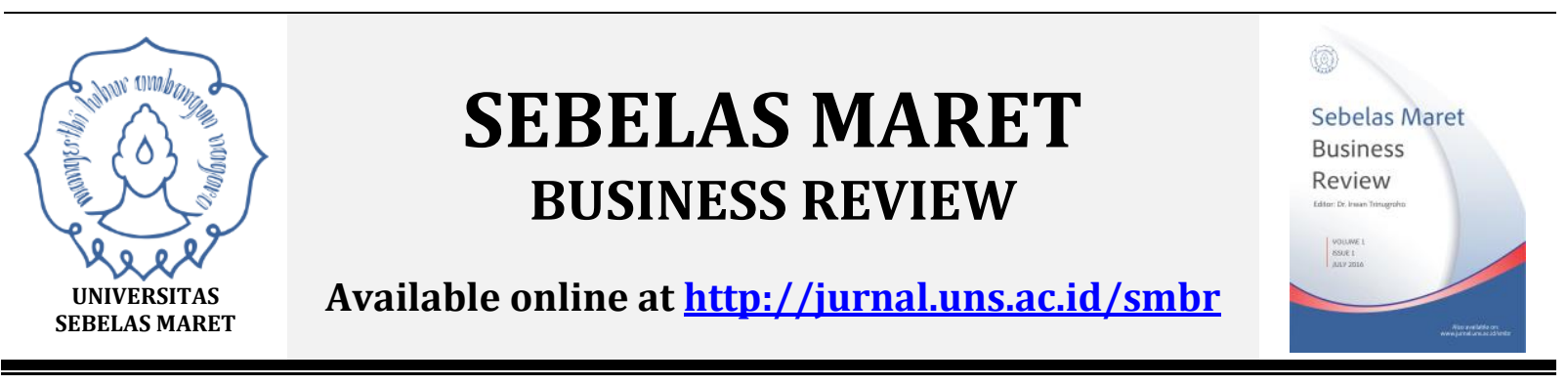

\title{
The Role Of Corporate Brand Image And Service Quality On Client Satisfaction With Perceived Value As Mediating Variable (A Study In The Construction Of Civil Registration Service Building, Surakarta)
}

\section{Ibnu Suryo ${ }^{a^{*}}$ and Asri Laksmi Riani ${ }^{a}$}

\author{
aMaster of Management, Sebelas Maret University, Ir. Sutami Street Number 36A, \\ Surakarta, Indonesia \\ *Corresponding author : ibnusuryo167@gmail.com
}

\begin{tabular}{|c|c|}
\hline ARTICLE INFO & ABSTRACT \\
\hline Article History: & \multirow{17}{*}{$\begin{array}{l}\text { This research aims to understand the effect of brand } \\
\text { image and service quality on employee's satisfaction who } \\
\text { is involved in the committee or Committee of Work Result } \\
\text { Receiver (Panitia Penerima Hasil Pekerjaan - PPHP) in a } \\
\text { construction project of civil registration service building } \\
\text { in Surakarta, conducted by PT. Karsa Bayu Bangun } \\
\text { Perkasa and PT. Surya Bayu Sejahtera, as well as to } \\
\text { examine the role of perceived value as mediating variable. } \\
\text { We distribute research questionnaires to } 30 \text { institution } \\
\text { staffs. The data is examined using Structural Equation } \\
\text { Model (SEM) to measure the role of corporate brand } \\
\text { image and service quality with perceived value as } \\
\text { mediating variable on client satisfaction. The result shows } \\
\text { that corporate brand image has a significant direct effect } \\
\text { on perceived value and client satisfaction, service quality } \\
\text { also has a significant direct effect on perceived value and } \\
\text { client satisfaction. Perceived value has a significant direct } \\
\text { effect on client satisfaction. Meanwhile, corporate brand } \\
\text { image has an indirect effect on client satisfaction through } \\
\text { perceived value. However, service quality does not have } \\
\text { an indirect effect on client satisfaction through perceived } \\
\text { value, which means perceived value does not mediate the }\end{array}$} \\
\hline Received 15 February & \\
\hline & \\
\hline Received in Revised Form & \\
\hline $\begin{array}{l}\text { Accepted } 20 \text { April } 2017 \\
\text { Available online } 1 \text { May }\end{array}$ & \\
\hline 2017 & \\
\hline Keywords: & \\
\hline Corporate Brand Image, & \\
\hline Service Quality, & \\
\hline Value, Client & \\
\hline Satisfaction. & \\
\hline & \\
\hline & \\
\hline & \\
\hline & \\
\hline & \\
\hline & \\
\hline
\end{tabular}


effect of service quality on client satisfaction.

\section{INTRODUCTION}

Construction industry is a dynamic entity which characterized with many uncertainties in technology, budget, and construction process (Chan and Chan, 2004). Client satisfaction is an important aspect for a construction company in the construction process which is related with establishing a relationship with client. In order to maintain a competitiveness in construction industry, a contractor should ensure that they have a good corporate brand image and providing excellent service to fullfil client's satisfaction.

Service quality and perceived value are two constructs that can not be separated from client satisfaction evaluation process. There are many studies on correlation between service quality, perceived value, and customer/client satisfaction (Howat \& Assaker, 2013; Park, Robertson, \& Wu, 2006; Yu et al., 2014.). Corporate brand image refers to a set of values which represent a company (Ind, 1997), and a positive corporate brand does not only help a company to increase its competitiveness but also encourage customers to repurchase their product (Porter \& Claycomb, 1997). Moliner, Sanchez, Rodriguez, and Callarisa (2007) state that customer perceived value consist of functional value of goods or service and price, emotional value and social impact of the usage of previous goods and service.

\section{LITERATURE REVIEW AND HYPOTHESIS}

\section{Contractor}

Construction project can be defined as a project which involves several parties with complex processes, thus each construction project has its own characteristic (Santoso, 2004). Meanwhile, construction project according to Ervianto (2005) is an interrelated activities which is performed once in a while and for a short period. Within the activities, there is a process of managing the project's resource and transform it into a building.

The successfulness of a construction project is not only viewed from its physical outcome, but also from the achievement of its functional objective. Therefore, a good cooperation between each element involved in the construction process.

\section{Corporate Brand Image}

Keller (1993) defines brand image as a perception about a brands in customer's/client mind. Corporate Brand Image is an intangible asset for a company and is difficult to imitated, in this term 'it' is different with the brand of a product which emphazise on the importance of brand's value (De-Chernatony, 1999). With a good corporate brand image, customer's perception on quality, value, satisfaction, and loyality will be favorable (Johnson, Andreessen, Lervik \& Cha, 2001). Aaker (1996) states that corporate brand image can be measured using three dimensions such as: brand value, brand characteristic, and brand association. 


\section{Service Quality}

Most of client satisfaction masurement is conducted through an approach which involves subjective perception based on objective issues. In an construction industry, client satisfaction measurement is mostly related with performance and quality assessment service in term of project or service received by client (Parasuraman et al., 1985, 1988; Soetanto and Amsal, 2004). The focus of client satisfaction achievement conducted by construction company generally is to continue to satisfy client needs in the projects and that their project meet the expectation of owner/client.

Parasuraman et al. (1988) develop SERVQUAL model which is based on their previous research (Churchill and Serprenant, 1982;. Parasuraman et al., 1985) and states that even though each service companies has their own unique characteristics in several aspect, there are five general dimension of service quality that is applicable universally, such as: reliability, responsiveness, assurance, empathy, and tangibles.

\section{Perceived Value}

Previous studies (Howat \& Assaker, 2013; Tam, 2004; Yu et al., 2014) conclude that service quality increase the value perceived by client. If client spent less money, time, and energy compared with the service they received, thus client will perceive a higher value for the service they get. In the other word, the better service quality, the higher client perceived value (Howat \& Assaker, 2013; Tam, 2004; Yu et al., 2014). Perceived value is undoubtedly is the trigger for client satisfaction. When a client receives a high value of a service, it will lead to high satisfaction.

Basically, client satisfaction is a reaction on the value received in the exchange process (Woodruff and Gardial, 1996). Therefore, company's manager/leader should consider some points that is appreciated by client before implement the measures to improve client satisfaction, henceforth monitoring organization's performance.

Client's perceived value is operationalized as multidimensional. There are five dimensions i.e. quality $(\mathrm{Q})$, emotional value $(\mathrm{EV})$, price $(\mathrm{P})$, social value $(\mathrm{SV})$ and reputation (R), these dimensions derived from Sweeney and Soutar (2001), PERVAL and Petricks (2002).

\section{Client Satisfaction}

Client is considered as the most important stakeholder in each construction project. Alinaitwe (2008) defines client as individual, companies, or government who is responsible to settle off the payment for the design of a building's construction and the facility used. The importance of client can be viewed from the fact that they bear most of the risk in providing project's necessity, which is the requirement in each construction companies.

Moreover, the importance in achieving client satisfaction can be seen from their position as the employer of the parties involved in a development of a project. Owner is involved in a project and is responsible for the payment, in the case of contractor service, the owner has the power to decide among the bidders who will eventually win the contract and execute the project. Besides that, owner's satisfaction on contractor usually become the basis of contractor involvement in a project. 
According to Abayomi Omonori and Akinloye Lawal (2014) construction company's client satisfaction can be assessed by measuring: Quality Rating, Delivery Schedule Rating, Price Rating.

Research Framework Model

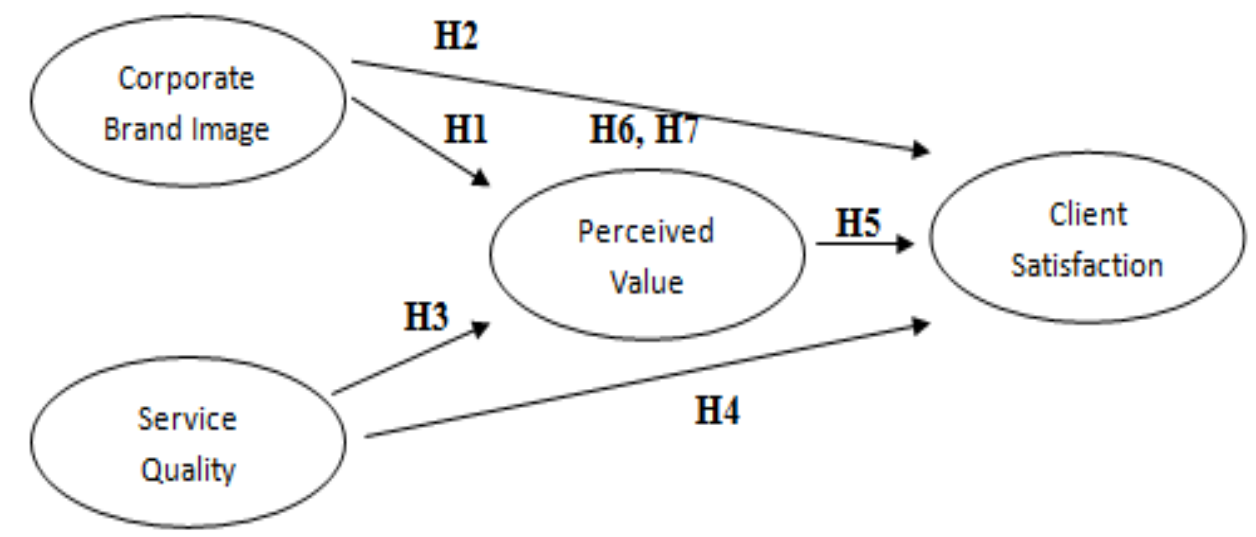

Hypotheses:

$\mathrm{H} 1$ : there is a significant positive effect of corporate brand image on perceived value.

H2 : there is a significant positive effect of corporate brand image on client satisfaction.

H3 : there is a significant positive effect of service quality on perceived value.

H4 : there is a significant positive effect of service quality on client satisfaction.

H5 : there is a significant positive effect of perceived value on client satisfaction.

H6 : Perceived value mediates the effect of corporate brand image on client satisfaction.

H7 : Perceived value mediates the effect of service quality on client satisfaction.

\section{METHODOLOGY}

\section{Constructs Operationalization and Questionnaire Development}

The terms that should have empirical reference (can be measured, calculated, or collected through good reasoning), which is expressed in criteria/operation/dimension that can be measured specifically, are depend on research objective and how it can be measured. Variables measurement in this research is adopted from an instrument with five Likert scale, where 1 refers to strongly disagree opinion and 5 refers to strongly agree opinion. The assessment of corporate brand image is measured using 3 item of questions, service quality measured using 5 item of questions, perceived value measured using 5 item of questions, and client satisfaction is measured using 3 item of questions.

In order to obtain a valid and reliable data, a valid and reliable research instrument is needed. Therefore, before the data collection is performed, a validity and reliability test is firstly performed on research questionnaires. Validity test is a test performed on the content of an instrument, which aims to assess the accuracy of an instrument used in a research. Validity test shows to what extent an instrument 
(indicator) can measure certain variable (Zikmund et al., 2006). An indicator is valid if it has value of corrected item total correlation $\geq 0.1981$. Reliability test is conducted to determine the consistency of a measurement if it is performed continuously (Zikmund et al., 2006). A variable measurement is considered reliable if it has Gronbach $\alpha$ value $\geq$ 0.60 .

\section{Data Collection}

We use census by including all member of the population as research sample. This is due to the size of this research population which is relatively small ( 30 people) and by generalizing the sample, it is expected to minimize error in this research. The sample in this research is employees who is involved in the committee or PPHP in a construction project of civil registration service building in Surakarta.

\section{Data Analysis Technique}

The model in this research will be analyzed using Structural Equation Model (SEM), which will be performed in PLS (Partial Least Square) software. PLS is considered to be suitable for predicting and building a theory, whereas only small amount of sample is needed (Ghozali, 2013). The advantage of PLS is, it can estimate a research model's size at a certain validity and reliability, as well as generating a parameter from a structural model which examines the power of the hypothesized correlations.

\section{RESULTS AND DISCUSSION}

Instrument tests in this research are including convergent validity, discriminant validity and composite reliability. The objective of these tests is to examine to what extent is the level reliability and validity of a research instrument. Convergent validity is performed by comparing the value of outer model (loading factor) with the critical value 0.5 . If the loading factor is $>0.5$, thus the instrument is valid, vice versa. The second validity test is the discriminant validity test which aims to examine construct's validity by measuring AVE (Average Variance Extracted) root, and comparing the correlation of a construct to another construct. This research model can be considered to have a proper discriminant validity value if the AVE root value for each construct is greater than the correlation of a construct to another construct in the model. The output of PLS is presented in Table 4.11 below:

Tabel 4.11

Diskriminan Validity

\begin{tabular}{c|ccc}
\hline Variable & Brand Image & $\begin{array}{c}\text { Client } \\
\text { Satisfaction }\end{array}$ & Perceived Value Service Quality \\
\hline Brand Image & $0.928^{*}$ & & \\
Client Satisfaction & 0.727 & $0.868^{*}$ & \\
Perceived Value & 0.652 & 0.800 & $0.803^{*}$
\end{tabular}




\begin{tabular}{c|cccc}
\hline Variable & Brand Image & $\begin{array}{c}\text { Client } \\
\text { Satisfaction }\end{array}$ & Perceived Value & Service Quality \\
\hline Service Quality & 0.489 & 0.743 & 0.570 & $0.865^{*}$ \\
\hline
\end{tabular}

Based on table above, it can be concluded that AVE root value for all constructs is greater than the correlation between the variables, as presented in Table 4.11. As an example, the variable brand image has an AVE root value of 0.928 . This value (the AVE root value) is greater, if compared to the correlation coefficient of corporate brand image to other constructs, which has a correlation coefficient between $0.489,0.652$, and 0.727 . Therefore, the construct of performance is valid, because the value of AVE root $>$ its correlation coefficient. This method also applied for other variables, thus it can be concluded that all variables in this research has a high discriminant validity.

The reliability of all constructs can be measured using composite reliability value. If a construct has a composite reliability which is greater than 0.70 thus, it is reliable. The table below summarize the result of data processing using PLS.

Tabel 4.13

\section{Composite Reliability}

\begin{tabular}{c|c}
\hline & $\begin{array}{c}\text { Composite } \\
\text { Reliability }\end{array}$ \\
\hline Brand Image & 0.949 \\
$\begin{array}{c}\text { Client } \\
\text { Satisfaction }\end{array}$ & 0.902 \\
Perceived Value & 0.898 \\
Service Quality & 0.936 \\
\hline
\end{tabular}

Hypothesis test is performed by considering the significance level and path parameter between latent variable. Hypothesis is formulated to examine the relationship between each construct. Conclusion is taken based on the correlation direction and model significance. The result is presented in Table 4.15, which is the output of inner weight using PLS 3.0 software.

Table 4.15

The Direct Effect between Construct

\begin{tabular}{cccccc} 
& $\begin{array}{c}\text { Original } \\
\text { Sample (O) }\end{array}$ & $\begin{array}{c}\text { Sample } \\
\text { Mean (M) }\end{array}$ & $\begin{array}{c}\text { Standard } \\
\text { Deviation } \\
\text { (STDEV) }\end{array}$ & $\begin{array}{c}\text { T Statistics } \\
(\mid \mathrm{O} / \text { STDEV|) }\end{array}$ & $\begin{array}{c}\mathrm{P} \\
\text { Values }\end{array}$ \\
\hline $\mathrm{BI}->\mathrm{CS}$ & 0.280 & 0.281 & 0.114 & 2.449 & 0.015
\end{tabular}




\begin{tabular}{|c|c|c|c|}
\hline $\begin{array}{c}\text { Original } \\
\text { Sample (0) }\end{array}$ & $\begin{array}{c}\text { Sample } \\
\text { Mean (M) }\end{array}$ & $\begin{array}{l}\text { Standard } \\
\text { Deviation } \\
\text { (STDEV) }\end{array}$ & $\begin{array}{l}\text { T Statistics } \\
(\mid 0 / \text { STDEV } \mid)\end{array}$ \\
\hline
\end{tabular}

\begin{tabular}{r|rrrrr}
\hline BI -> PV & 0.490 & 0.495 & 0.145 & 3.388 & 0.001 \\
PV -> CS & 0.402 & 0.417 & 0.120 & 3.354 & 0.001 \\
SQ - CS & 0.377 & 0.353 & 0.122 & 3.080 & 0.002 \\
SQ -> PV & 0.330 & 0.345 & 0.155 & 2.132 & 0.034 \\
\hline
\end{tabular}

Based on Table 4.15, we can find the effect of exogenous variables on endogenous variable. The first hypothesis test result shows that the coefficient of the effect of corporate brand image on perceived value is 0.490 with t-value of 3.388 and $p$ value $=0.001<0.05$ at significance level of $5 \%$. The second hypothesis test result shows that that the coefficient of the effect of corporate brand image on client satisfaction is 0.280 with $t$-value of 2.499 and $p$ value $=0,016<0.05$ at significance level of $5 \%$. The third hypothesis test result shows that that the coefficient of the effect of service quality on perceived value is 0.330 with $t$-value of 2.132 and $p$ value $=0.034<0.05$ at significance level of $5 \%$. The fourth hypothesis test result shows that that the coefficient of the effect of service quality on client satisfaction is 0.377 with $t$-value of 3.080 and $p$ value $=0.002<0.05$ at significance level of $5 \%$. The fifth hypothesis test result shows that that the coefficient of the effect of perceived value on client satisfaction is 0.402 with $t$-value of 3.354 and $p$ value $=0.001<0.05$ at significance level of $5 \%$.

Meanwhile, the result of indirect effect is presented in Table 4.16.

Table 4.16

The Result of Indirect Effect

\begin{tabular}{|c|c|c|c|c|c|}
\hline & $\begin{array}{c}\text { Original } \\
\text { Sample (0) }\end{array}$ & $\begin{array}{c}\text { Sample } \\
\text { Mean (M) }\end{array}$ & $\begin{array}{c}\text { Standard } \\
\text { Deviation } \\
\text { (STDEV) }\end{array}$ & $\begin{array}{c}\text { T Statistics } \\
(\mid 0 / \text { STDEV } \mid)\end{array}$ & P Values \\
\hline $\mathrm{BI}->\mathrm{CS}$ & \multirow[t]{3}{*}{0.197} & \multirow[t]{3}{*}{0.208} & \multirow[t]{3}{*}{0.088} & \multirow[t]{3}{*}{2.239} & \multirow[t]{3}{*}{0.026} \\
\hline $\mathrm{BI}->\mathrm{PV}$ & & & & & \\
\hline $\mathrm{PV} \rightarrow \mathrm{CS}$ & & & & & \\
\hline SQ $->C S$ & \multirow[t]{2}{*}{0.133} & \multirow[t]{2}{*}{0.143} & \multirow[t]{2}{*}{0.080} & \multirow[t]{2}{*}{1.649} & \multirow[t]{2}{*}{0.100} \\
\hline SQ -> PV & & & & & \\
\hline
\end{tabular}


Based on Table 4.15, we can find the effect of exogenous variables on endogenous variable through mediating variable. The sixth hypothesis test result shows that the coefficient of the effect of brand image on client satisfaction through perceived value is 0.197 with $t$ value of 2.239 and $p$ value $=0.026<0.05$ with significance level of 5\%. The sixth hypothesis test result shows that the coefficient of the effect of service quality on client satisfaction through perceived value is 0.133 with $\mathrm{t}$-value 1.649 and $\mathrm{p}$ value $=0.100>0.05$ at significance of $5 \%$.

\section{CONCLUSION}

Corporate brand image significantly affect perceived value and client satisfaction of the employees involved in committee/PPHP in a construction project of civil registration service building in Surakarta. Service quality significantly affect perceived value and client satisfaction directly. Based on data analysis result, we find that perceived value has an indirect significant effect on client satisfaction. Moreover, corporate brand image also has an indirect significant effect on client satisfaction through perceived value. Service quality does not have an indirect effect on client satisfaction through perceived value of the employees involved in committee/PPHP in a construction project of civil registration service building in Surakarta. This means, perceived value does not mediate the effect of service quality on client satisfaction.

\section{REFERENCES}

A.B., Schaufeli, M., Leiter, \& C., Maslach. 2009. Burnout: 35 years of research and practice. Journal Career Development International, Vol. 14 No. 3, pp. 204-220

Ervianto, Wulfram I. 2005. Manajemen Proyek Konstruksi, Salemba Empat, Yogyakarta.

Ghozali, I. 2011. Partial Least Squares Konsep, Teknki dan Aplikasi Menggunakan Program Smartpls 3.0 Untuk Penelitian Empiris Semarang: Badan Penerbit UNDIP.

Gill, D., Byslma, B., and Ouschan. R. 2007. Customer perceived value in a cellar door visit: the impact on behavioural intentions. International Journal of Wine Business Research, 19 (4), 257-275.

Hapsari, R., Clemes, M., and Dean, D. 2015. The mediating role of perceived value on the relationship between service quality and customer satisfaction: Evidence from Indonesian airline passengers. Procedia Economics and Finance 35, 388 - 395.

Kärnä, S., Junnonen, J, M., and Kankainen, J. 2016. Customer satisfaction in construction. Research Paper.

Kotler, Amstrong. 2010. Principles of Marketing. 13 Edition. New Jersey. Upper Saddle River: Pearson Prentice H.

Kotler, Philip; Armstrong, Garry. 2008. Prinsip-prinsip Pemasaran, Jilid 1. Erlangga, Jakarta.

M.A.N, Masrom, M, Skitmore. 2011. Developing a conceptual model for measuring the satisfaction levels of Malaysian contractors. Research Paper, 245-257.

Omonori, A., Lawal, A. 2014. Understanding customers' satisfaction in construction industry in Nigeria. Journal of Economics and Sustainable Development, 5 (25), $115-120$.

Rahman, A., Alzubi, Y. 2015. Exploring Key Contractor Factors Influencing Client Satisfaction 
Level in Dealing with Construction Project: an Empirical Study in Jordan. International Journal of Academic Research in Business and Social Sciences, 5 (12), 109 - 126.

Margono. 2004. Metodologi Penelitian Pendidikan. Jakarta: Rineka Cipta.

Santoso, Budi. 2004. Manajemen Proyek, Guna Widya, Surabaya.

Setiawan, H., Erdogan, B., and Ogunlana, S. 0. 2015. Competitive aggressiveness of contractors: A study of Indonesia. Procedia Engineering 125, 68 - 74.

Sugiyono. 2001. Statistik untuk Penelitian. Bandung: Alfabeta.

Tu, Y. T., Li, M. L., and Chih, H. C. 2013. An empirical study of corporate brand image, customer perceived value and satisfaction on loyalty in shoe industry. Journal of Economics and Behavioral Studies, 5 (7), 469-483. 